\title{
The Central Synagogue of Nazareth Illit and its architectural dialogue with Nazareth's Basilica of the Annunciation
}

\author{
Naomi Simhony (iD ${ }^{1 凶}$
}

The hometown of Jesus, Nazareth, is an international center of Christian pilgrimage that has capitalized on showcasing its sacred sites. Architect Antonio Barluzzi was commissioned to design Nazareth's modern Basilica of the Annunciation in 1954, and a cornerstone for the project was laid in a well-attended ceremony. It seems that the establishment of the modern church was the catalyst for the eagerness with which the Israeli authorities approached establishing a Jewish monument in the region. In 1957, a design process for the Central Synagogue in Nazareth Illit (subsequently renamed Nof HaGalil) began, with the aim of proudly competing with the churches and mosques in the Nazareth region. Both the basilica and the synagogue were erected by Israeli construction firm Solel Boneh and were inaugurated in 1968 and 1969, respectively. This article examines the impact of the inception, establishment and building of Nazareth's Basilica of the Annunciation on the drive to strengthen Jewish presence in the Nazareth region, which in turn stood behind the construction of the Nazareth Illit synagogue. This research is based on a comparative investigation of the histories of both structures, including early design proposals, architecture, and the religious artworks therein. This comparative investigation reveals the influence of the basilica on the synagogue and the shared aspects of their design and execution. While existing literature dedicated to the Central Synagogue in Nazareth Illit has focused on its significance and meaning as an Israeli architectural landmark, this article presents a new perspective, examining how a modern architectural trend was used as an agent in the struggle between local Jewish and Christian monumental dominance. It also contributes to the literature by shedding light on a heretofore overlooked quest for an appropriate architectural style for religious buildings in the Land of Israel during the mid-twentieth century.

\footnotetext{
${ }^{1}$ The Hebrew University of Jerusalem, Jerusalem, Israel. ${ }^{凶}$ email: naomi.simhony@mail.huji.ac.il
} 


\section{Introduction}

he hometown of Jesus, Nazareth is an international center of Christian pilgrimage that proudly showcases its sacred sites. Nazareth Illit was established as a development town in $1956,{ }^{1}$ by way of implementing Prime Minister David BenGurion's policy of expanding Jewish presence in the Galilee. ${ }^{2}$ In a letter written in 1957, Ben Gurion stated that: "the new settlement must be a Jewish town that will assert Jewish presence in the area. Not a suburb of Arab Nazareth, but a separate town in its vicinity" (Rabinowitz, 1997, p. 3, 6). ${ }^{3}$ According to Mordechai Alon, Nazareth Illit's first mayor, "the idea for the city originated in 1954." In that year, architect Antonio Barluzzi was commissioned to design the modern Basilica of the Annunciation, the 18 th-century church that stood on the cite was demolished, and a cornerstone for the modern basilica was laid in a well-attended ceremony (Halevi, 2010, p. 28, 33). Given the policy imperatives of the government, it is reasonable to assume that the establishment of the modern church was the catalyst for the Israeli authorities' eagerness to establish a Jewish monument in Nazareth region. In 1957, a design process for the Central Synagogue in Nazareth Illit began, with the aim of "proudly competing with non-Jewish houses of worship in the Nazareth region." ${ }^{5}$ Both the synagogue and the basilica were erected by Israeli construction firm Solel Boneh and inaugurated in 1968 and 1969, respectively (Tvai, 1970).

Although research about Nazareth Illit's Central Synagogue has illuminated its exceptional design and national significance as an architectural landmark (Amir, 2011, pp. 30-32; Harlap, 1985, pp. 128-129), this article explores the synagogue's design history in light of its implicit architectural dialogue with Nazarath's Basilica of the Annunciation. ${ }^{6}$ I highlight three parallel moments in the design histories of the structures. First the eclectic style of the early design proposals submitted by architect Antonio Barluzzi (1954) and architect Meir Ben Uri (1957). Second, the Brutalist style of the structures, designed by architect Giovanni Muzio (1958-1969) and architect Nahum Zolotov (1960-1968). Third, parallels in the artworks that were integrated into the structures. This comparative framework allows for a thorough examination of the impact of the establishment of Nazareth's Basilica of the Annunciation on the authorities' eagerness to strengthen Israeli nationality by means of a religious landmark, which in turn led to the Nazareth Illit synagogue design. The key questions this article tackles are: What were the respective aims behind the establishment of each religious monument? And, to what extent did religious competition in the Nazareth region impact the development of the synagogue's identity as a national architectural landmark? The design proposals, architecture, and religious artworks are compared in chronological order, to highlight the similarities and differences in motivation, ideology and approach that stood behind the construction of both structures.

This analysis is based on an architectural-historical investigation of the case studies, emphasizing their rootedness in the local history of the Nazareth region and augmented by insights from four additional fields: history and theory of architecture, anthropology, Israel studies and art history. By mobilizing diverse methodological approaches, this analysis reveals a heretofore overlooked contest in the quest for an appropriate style for religious architecture in the Land of Israel during the mid-20th century, demonstrating how modern architectural styles were utilized as agents in the struggle between Jewish and Christian religious sites in the Nazareth region.

Jewish-Christian religious competition. In his book, The Sacred Gaze: Religious Visual Culture in Theory and Practice, David Morgan stated that the history of interactions between religions is a history of a cultural rivalries. Religious belief has the power to become the symbol through which people understand their relations with other groups. Throughout history, distinguishing and differentiating one's own group from others with divergent religious belief has been marked by iconoclasm and ritualized acts of violence (Morgan, 2005, p. 115). For example, Christian hostility toward the Jews led to the burning of synagogues and forced conversion to Christianity at various points in history (Wischnitzer, 1964, p. xxvii).?

Despite the simultaneous existence of violent struggles, Morgan indicates that when an appropriated image is transferred from one religion to another, it preserves its original identity while adapting its form and use to the new context. In his view, by adapting a rival's symbol, a religious community affirms its religious identity as universal (Morgan, 2005, p. 151). The present study explores a nuanced modern expression of religious rivalry, evident in the architectural dialogue between the Central Synagogue of Nazareth Illit and Nazareth's Basilica of the Annunciation (Simhony and Gordon, 2018, p. 18). ${ }^{8}$ In this instance, the construction of the monumental basilica in Nazarath impacted the establishment and design of the synagogue through a dialectic interplay of visual similarity and separation.

Over the centuries, Jewish and Christian houses of worship in different places have embodied numerous similarities and differences, as reflected in the interior organization of synagogues and Catholic churches, which both cater to communal assembly (Wischnitzer, 1955, p. 4; Marshall, 1997, pp. 81-100). A major cause of similarity between synagogues and churches is their assimilation to local environments. Israel L. Levin maintains that synagogue architecture always adopted prevalent local styles and never developed a distinct architectural identity (Levin, 2000b, pp. 118-120). There is early evidence of this tendency in the adoption of the secular Roman Basilica as a model for ancient synagogues. A parallel tendency characterizes ancient church design (Wischintzer, 1964, pp. xxvii-xxviii; Krinsky, 1985, p. 15). ${ }^{9}$

Jewish mobility and settlement throughout the Diaspora resulted in exchanges of architectural concepts across regions and periods. Synagogues constructed in Europe in the early modern period reflect the influence of their environment through use of materials, adaptations to local climate, and expressions of local Christian culture (Wischintzer, 1964; Krinsky, 1985; Kravtsov, 2010, 2016). In contrast, synagogues constructed in the Islamic world reflect the influence of Middle Eastern and Mediterranean environments. The impact of local climate is evident, for example, in the design of the courtyard, which was occasionally used for prayer during summer (Snyder, 2013; Gharipour, 2017, pp. 11-13; Fine, 2019). Contrastingly, American Jewish communities were largely fashioned by waves of Jewish immigration, which followed persecution of the Jews in Eastern Europe in the 17th century and then Jewish refugees escaping Europe before and after the Second World War. As a result, synagogues constructed in the United States reveal tensions between the immigrants' past experiences and their new live (Wischintzer, 1955, pp. 3-4; Gruber, 2003; Kampf, 1966). Ultimately, this architectural exchange reflects the involvement of non-Jewish builders and artists in synagogue design. Until the 19th century there were very few Jewish architects, as for many centuries construction was controlled by medieval guilds that denied admission to Jews (Wischnitzer, 1964, p. xxix; Sabar, 2000, p. 310; Gharipour, 2017, p. 13).

Though there may be local similarities and parallels between the architecture of synagogues and churches, the liturgy practiced therein has always been fundamentally different. While in Catholic churches the priest leads worship and administers the sacraments, Jewish prayer is characterized by communal 
participation (Krinsky, 1985, p. 17). This difference is embodied in the design of prayer halls in synagogues and churches. While the church's sanctuary boasts a single focal point located at the alter, the synagogue has two focal points: the Torah Ark (the cabinet that houses the Torah scrolls) and the bimah (a central platform, utilized for Torah reading), which are connected when the scrolls are carried to the bimah (Shalev-Eyni, 2014, pp. 166-169; Krautheimer,1994, pp. 47-94, 102-125; Krinsky, 1985, p. 17).

Church and synagogue architecture following World War II. Twentieth century religious architecture has received relatively little scholarly attention. ${ }^{10}$ Karla Britton has outlined the major approaches that shaped modern church design, of which I will highlight three: the exploration of new materials, the search for new forms, and the impact of the second Vatican council.

Modern church architecture is characterized by the use of new materials. Architect Auguste Perret's Church of Notre Dame $d u$ Raincy (1923) is considered to have instigated this pivotal development in the evolution of modern church architecture. His design set in motion several ideals that were prevalent throughout the history of 20th century church design, including experimentation with new materials and technology, and the development of a new language of monumentality within the constraints of a particular religious tradition Perret's work set the stage for numerous structural and morphological explorations with concrete, which shaped the 20th century religious architecture. Architectural historian Adrian Forty proposes that the extensive use of concrete in modern churches reflects an attempt to redeem the material from its perception as a mundane material (Forty, 2012, p. 169; Britton, 2001, pp. 10-44, 2012, pp. 27-28).

The second characteristic feature of modern church design is the search for new forms. Modern religious culture experienced a major crisis as traditional faith affiliation, communal cohesion, and the centrality of religious monuments declined after the Second World War. This led contemporary architects to reject the rationality associated with the modern movement and experiment with new forms. One example of this trend is Antonio Gaudi's Templo de la Sagrada Familia in Barcelona (begun, 1882). Gaudi's design is considered to evoke "another" modernism, lying outside the traditional rationalism, and representing a universal, secular spirituality (Britton, 2012, pp. 28-29).

Third, the desire of the Catholic Church to foreground its universal spirit has impacted modern church design. The Second Vatican Council (1962-1965) encouraged Catholic congregational participation in liturgical celebrations and the ordination of priests of different races. These decisions demonstrated the universal spirit of modern Catholicism (Kenaan-Kedar, 2009, p. 84; Longhi, 2020, pp. 69-94). The adoption of modern architecture and experimental styles in 20th century Catholic churches demonstrates the increasingly modern, liberal approach emanating from the Vatican (Christ-Janer and Foley, 1962, p. 3).

Both modern synagogues and churches reflect the influence of major trends in contemporary international architecture. However, I maintain that Israeli synagogue design is rooted in the unique conditions that structured local architecture in the first decades after Israel's independence in $1948 .{ }^{11}$ The unprecedented number of new synagogues built at the time was the result of the rapid growth of new towns across Israel (Efrat, 2004, p. 251, 56). According to Rabbinic sources, every Jewish settlement must have a house of worship (Joseph Karo, Shulhan Arukh, Orah Hayim150: 1). However, consolidating the architectural identity of the Israeli synagogue presented a significant challenge to designers. Historically, as discussed above, the synagogue had not been bound to an inimitable style (Kampf, 1966, p. 27). Though Rabbinic literature includes some instructions for the interior arrangement of synagogues, there are not architectural guidelines regarding the exterior of the building, other than orienting it towards Jerusalem (Krinsky, 1985).

The modern appearance that characterizes synagogues constructed in Israel's early years differed from ancient synagogues built in the Holy Land, as well as from early modern European synagogues. Local architects remodeled traditional synagogue typologies by experimenting with major trends in modern architecture (eclectic style, high modernism, Brutalism). This is evident in the adoption of European Brutalism in both structures under examination in this article. ${ }^{12}$

Architect Meir Ben-Uri, advisor to the Ministry of Religious Affairs, pointed out a halakhic (Jewish legal) restriction on imitating non-Jewish diasporic architectural styles in synagogues designed in the State of Israel (Ben-Uri, 1955, pp. 195-242). In his view, adopting diasporic architecture was not an appropriate starting point for consolidating Israeli synagogue architectural identity. Despite Ben Uri's protestations, the architectural dialogue between the Central Synagogue in Nazareth Illit and Nazareth's Basilica of the Annunciation, on which this article focuses, illustrates the impact of Jewish-Christian religious competition on the consolidation of the Israeli synagogue architecture.

\section{Nazareth's Basilica of the Annunciation and Nazareth Illit's Central Synagogue: three parallel moments}

Early design proposals. The very structure of Nazareth's Basilica of the Annunciation symbolizes the sacred event in which, according to the New Testament, the angel Gabriel announced to the Virgin Mary that she would bear the son of God (Luke 1:26-38). The modern basilica is constructed over the ruins of a church that had been erected on the site in the Byzantine period, with subsequently added Frankish and Franciscan edifices (Segal et al., 2020, p. 7). Masha Halevi states that the idea of erecting a new monument for the sacred event of the Annunciation originated in 1924. Architect Antonio Barluzzi (1884-1960) was appointed to the project. However, as a result of political tensions within the Catholic Church, the project was halted. By 1954, Barluzzi was a well-respected architect who had rebuilt most of the major Catholic churches in the Holy Land. His goal was to build the most internationally important church dedicated to the Annunciation in Nazareth, which would represent the Annunciation through the architectural composition of the basilica itself. Barluzzi perceived the establishment of the basilica as the Catholic Church's attempt at reconciliation with God after the horrors of World War II (Halevi, 2004, p. 9, 2010, p. 27).

Barluzzi's proposal reflected his eclectic style and the religious symbolism with which he wanted to imbue the structure. The plan included a domed rotunda, which enshrines the Byzantine Grotto (a sacred cave) at its center, surrounded by four transepts that compose a Greek cross. The 56-m high dome, culminating in a spiral lantern, symbolizes the relationship between the human and the divine, the finite and the infinite. Moreover, the structure's circular plan mirrored the iconography of a flower, symbolizing the etymological meaning of the name "Nazareth": (Fig. 1). The design integrated numerous traditional elements, such as domes, towers, and a colonnade, while the only modern features were simple decorations and the use of reinforced concrete (Halevi, 2010, pp. 28-30; Irace, 2020, p. 98).

According to Fulvio Irace, Barluzzi's proposal was rejected because it provided for insufficient preservation of the site's archeological findings. In 1954, a major excavation campaign began in search of historical artefacts. Barluzzi maintained that 


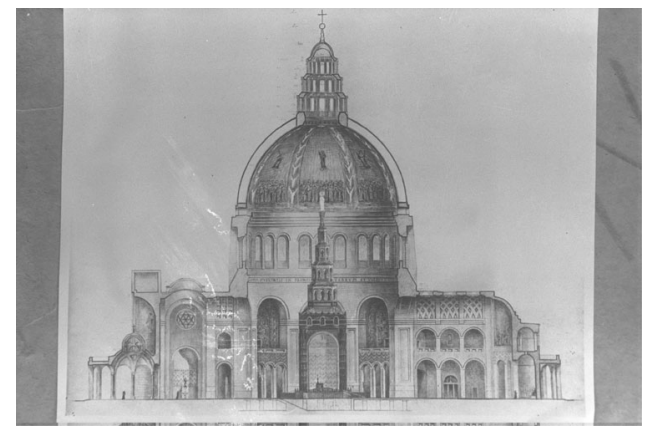

Fig. 1 The Basilica of the Annunciation, Nazareth, Architect Antonio Barluzzi's design proposal, Photographer unknown, 1954 (National Photo Collection, Photography Department, Government Press Office, State of Israel).

archeological considerations should yield to the architectural requirements of the new basilica, and so he considered moving the artefacts, namely parts of the ancient walls and the wainscoting of the medieval apses, to a museum annexed to the shrine rather than leaving them in situ, where they had been found. Moreover, it remained unclear how the project would emphasize the importance of the Grotto. Barluzzi's approach contradicted the approaches to architecture and conservation that were dominant in 1950s Italy, most notably that of Father Camillo Bellarmino Bagatti of the Order of Friars Minor, who was responsible for the excavation in Nazareth at the time. As a result, Barluzzi was required to revise his project, but he provided no response to the fundamental tension of the relationship between the archeological findings and his architectural design. Irace recently stated that this dissent resulted in his exclusion from the project. Muzio's involvement in the project began in 1958, and for a short period, the architects collaborated despite their opposing approaches. Barluzzi's illness led him move to Rome, where he died in 1960. (Irace, 2020, pp. 98-101; Halevi, 2004, p. 9; 2008, p. 89,95$)$.

A parallel architectural approach characterizes the early design proposal for the Central Synagogue in Nazareth Illit. The town was founded in 1956 as a Jewish development town overlooking the old city of Nazareth, in light of a state policy to settle Jews in the Galilee. Initiated and supported by Israeli governmental ministries, the synagogue design played a major role in realizing the state's policy. ${ }^{13}$ Architect Meir Ben-Uri, then an advisor to the Ministry of Religious Affairs, was appointed to design the project in 1957, on behalf of a governmental committee that managed the town's establishment. Ben Uri's design was instructed by the Deputy Minister of Religious Affairs, Zerach Warhaftig. ${ }^{14}$

Architect Meir Ben Uri (née Maximilian Wasbutzky in Riga, Latvia, 1908) was an alumnus of the Technical University of Berlin, ${ }^{15}$ who immigrated to Palestine in 1934 and died in Haifa in 1983. Oryan Shachar maintains that Ben Uri developed and articulated an original modern Jewish style that attempted to reflect the new national-Zionist conditions in the State of Israel. In Palestine, and then Israel, he designed many religious buildings and towns, as well as much Jewish art and many ceremonial objects. He also published a large number of related articles. However, though he was a visionary architect, and an observant religious man himself, thanks to his eccentric style that differed from the major trend in the Israeli architecture of the period, most of his synagogue designs remained unbuilt (Shachar, 2012, pp. 144-149; Shachar and Nitzan-Shiftan, 2014, pp. 118-125; Gafni, 2017, pp. 90-95; 2014, pp. 59-76; 2012, pp. 149-158).

Ben Uri's three floored synagogue building was designed to house 250 worshipers and aimed to project Jewish presence in the
Nazareth region. The proposal highlighted the difference between Jewish houses of worship and Nazareth's Christian and Muslim landmarks. The synagogue's location on the top of a hill demonstrated the synagogue's supremacy in its interreligious environment. This motif was further expressed by the architectural design: In contrast to the churches' bell towers, the synagogue's silhouette was designed in a shape of a tent and the highest point of the roof was located above the bimah. Through this design Ben Uri intended to project the particularly Jewish identity of the structure (Fig. 2). Unlike the churches' orientation to the east, the synagogue was oriented towards Jerusalem in the south. ${ }^{16}$

Ben Uri's proposal also integrated elements that directly competed with the Basilica's status as the religious focal point of the region. One such example is a display of findings from second century Galilean synagogues, apparently intended to demonstrate the affinity of the modern synagogue with local Jewish history. This aspect of the synagogue design simultaneously evokes the archeological museum of the Church of Annunciation, which presents some of the extensive findings recovered during the excavation that preceded the new building (Halevi, 2004, pp. 19-21).

Precursors to Ben Uri's works can be found in the Bezalel school. This affinity is demonstrated by the motivation to formulate a distinctive national style for the young country, and in the sources of influence at hand. ${ }^{17}$ The eclectic style of his proposal integrated modern construction technologies with Jewish symbols and elements adopted from ancient synagogues in the Land of Israel. This approach is evident in the synagogue's yard, that was shaped like a seven-branched candelabrum, as well as in the design of the synagogue's gates, which mimic the gates of the ancient upper Galilee Meron synagogue. Ben Uri's proposal was rejected, and the Ministry of Social Affairs initiated an architecture competition for the design of the synagogue. ${ }^{18}$

While the early design proposals for the Basilica of the Annunciation and the Central Synagogue in Nazareth Illit were designed by different architects from rival religious traditions, they reflect parallel architectural tendencies. Both proposals are marked by symbolism and eclectic styles that did not conform to the modern image with which the respective institutions of the Catholic Church and the State of Israel wanted to associate themselves at the time. Interestingly, both proposals reveal similarities in the buildings that were eventually erected. This parallel trend reflects the different political interests behind their construction.

The design history of the Basilica of the Annunciation, especially the turn from Barluzi's rejected proposal to Muzio's design, was affected by controversies between the various transnational authorities involved in its construction, such as the Custodia Terrae Sanctae and the Latin Patriarchate (Halevi, 2008, pp. 97-100). ${ }^{19}$ This process demonstrates that, beyond the memorialization of the sacred event of the Annunciation, the structure symbolizes the power of the Catholic church by demonstrating its presence in the modern day Holly Land (Halevi, 2008, p. 97).

The design history of Nazareth Illit's synagogue reflects the involvement of the young state's institutions in strengthening Jewish presence in the mixed environment of the Nazareth region, and their attempt to fashion a modernized Jewish identity, as is evident in the rejection of Ben Uri's proposal and the later adoption of Brutalism. This in turn echoes a broader turn from Bezalel's Hebrew style to the adoption of prevalent international modern trends (Fischer and Manor-Friedman, 2008, pp. 9-10). Interestingly, some of Ben Uri's design principles were eventually integrated in the architecture competition's guidelines and are evident in Nahum Zolotov's building. The synagogue court is one 


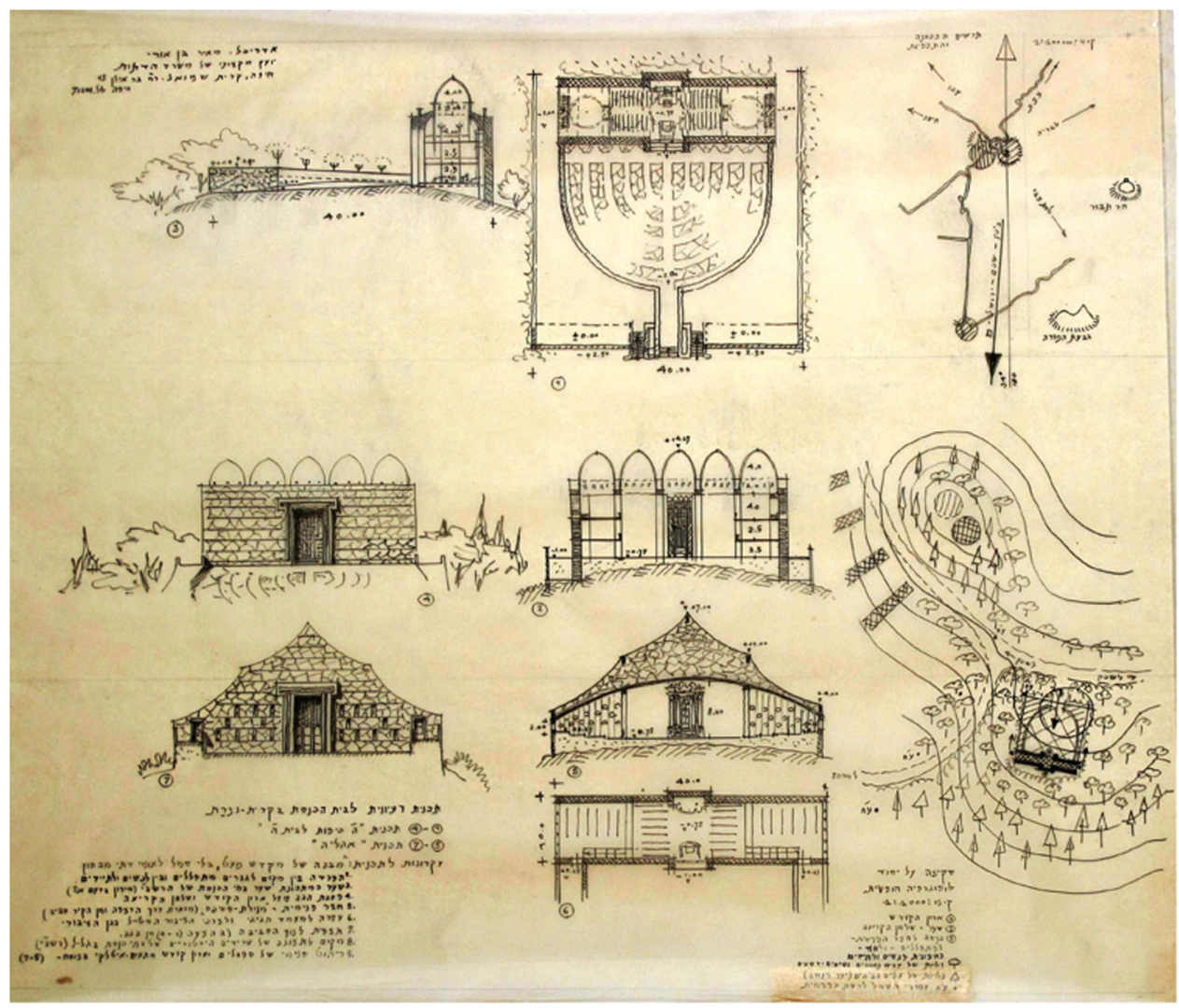

Fig. 2 The Central Synagogue of Nazareth Illit, Architect Meir Ben-Uri's design proposal, 1957 (Meir Ben Uri's Archive, Haifa. Kiryat Nazareth synagogue, file no. 320.00-0. Courtesy of Meir Ben Uri's Collection).

of many examples of the ways in which Ben Uri's work anticipated a consolidation of local identity in Israeli synagogue architecture.

Brutalism in religious architecture. The most clearly evident parallel in the design histories of the synagogue and the basilica is the adoption of the Brutalist style in both buildings. In 1958, Giovanni Muzio was commissioned to design the basilica. Construction took a decade and the basilica was inaugurated in 1969. Designed to accommodate 2000 worshipers, the modern Basilica of the Annunciation is considered to be the largest church in the Middle East (Halevi, 2004, p. 4). Muzio maintained that his intention was "to create a church-fortress, because this was the sixth church that had stood in the same site over the ruins of the demolition of the preceding ones" ${ }^{\prime 20}$ (Irace, 2020, p. 103). The architect's motivation to refine the relationship of the modern church to the landscape of the ruins and the Grotto was realized by constructing the Basilica on the perimeter of the Crusader-era church. The fortress image of the modern basilica was further emphasized by its monumental size, physical separation from the outside world (delineated by walls), and its stylistic differentiation from Nazareth's environment (Irace, 2020, p. 103; Halevi, 2010, p. 36). ${ }^{21}$

The basilica is comprised of two churches superimposed one on top of the other. An octagonal oculus traverses the churches, linking the Grotto to the dome atop the church. The oculus symbolizes the connection between the earthly and heavenly realms (Halevi, 2008, p. 86). The upper church is designated for the celebration of the liturgy. The lower church preserves and exhibits the findings from the Byzantine Grotto, and also functions as an active sanctuary. In contrast to Barluzzi's proposal, Muzio's design echoed the outline of the 12th century church that had been on the same site, enabling the display of the archeological findings next to the Grotto where they had been excavated. This display location reflects the church leaderships' belief that the relics testify to the authenticity of the place (Halevi, 2004, pp. 19-21). The Basilica complex also included a display of archeological findings preserved from the ancient village of Nazareth (Halevi, 2008, p. 96, 2010, p. 37). These archeological findings directly impacted the basilica's design; to preserve the traces of the ancient village, which Barluzzi had intended to destroy, Muzio suspended access to the upper church on pillars (Irace, 2020, p. 103; Halevi, 2010, p. 36).

The dominant element of the Basilica is the monumental dome, which, standing $55-\mathrm{m}$ high, dominates the city's skyline (Fig. 3). Nurit Kenaan-Kedar argues that this element, which projects light out to its surroundings, symbolizes the universal force of the church. The octagonal shape of both the oculus and the dome signifies eternal life in Christianity and evokes the affinity between the annunciation, Jesus's resurrection and his ultimate ascent to heaven (Kenaan-Kedar, 2009, pp. 80-82; Halevi, 2010, p. 36).

Giovanni Muzio (1893-1982) was a prominent Italian architect who designed a range of major Catholic monuments. His oeuvre is associated with the Novecento movement, whose work engaged in dialogue with historical styles, mainly the neo-classicist tradition, and rejected the contemporary European AvantGarde. In its early years, for a short period in the 1920s, the Novecento movement supported Italian fascism (Kenaan-Kedar, 2009, p. 77; Halevi, 2008, pp. 85-86). However, after this brief period, Muzio adopted the modern style, which is most clearly evident in his use of exposed concrete and the integration of contemporary artworks into the basilica (Halevi, 2010, p. 37). 


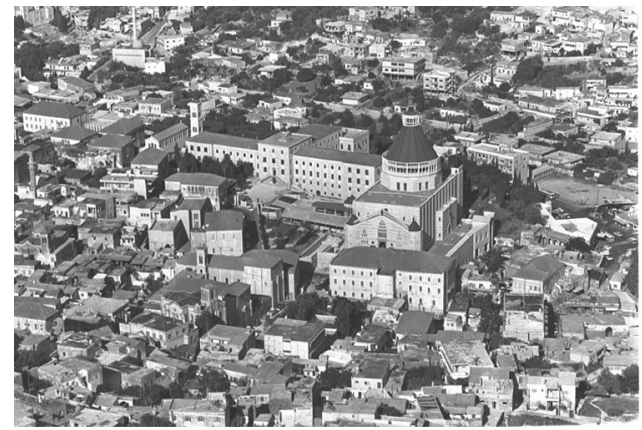

Fig. 3 The Basilica of the Annunciation, Nazareth, Architect Giovanni Muzio, 1969 (Photo: Moshe Milner, 1970, National Photo Collection, Photography Department, Government Press Office, State of Israel).

The adoption of Brutalism in the basilica reflects the artistic agenda decided at the Second Vatican Council (1962), which advocated adopting contemporary, prevalent artistic styles as an expression of the open and universal spirit of the church (Kenaan-Kedar, 2009, p. 83). Muzio integrated different styles into the design of the basilica: while Brutalism is evident in the exposed concrete that dominates the interior spaces, the exterior appearance is characterized by traditional Italian medieval style. The facades were covered with white stone and decorated with inscriptions and biblical scenes (Halevi, 2010, p. 81). Nurit Kenaan-Kedar identifies the Cathedral Square complex in Pisa, Italy, as a precedent for the design of the Basilica of the Annunciation. In her view, its dome recalls the domes of Pisa's Duomo (medieval cathedral) and Baptistery. The similarity is evident, for example, in a series of triangular arches and windows that encircle the dome (Kenaan-Kedar, 2009, p. 80).

The construction of a Christian monument in the early years of Israel's independent statehood reflects local and foreign political interests. The establishment of the basilica in Nazareth was promoted and supported by the Catholic Church-it reflected their interests in the Holy Land, as well as their warm diplomatic relations with the Israeli government. Israeli collaboration with the project was intended to highlight the State's liberal approach towards non-Jewish sacred places. Simultaneously, Israeli representatives perceived the establishment of the international landmark as an engine of development for the Nazareth region (Halevi, 2004, pp. 1, 27-31; 2010, p. 33). This approach was publicized in 1964, when Pope Paul VI visited Israel. Doron Bar indicates that Nazareth dominated the planned visit, and preparations included accelerating the Basilica's construction to enable the papal visit, alongside a major renovation of Nazareth's main street (Bar, 2015, p. 137).

An additional Israeli attempt to manifest interreligious tolerance in the region is evident in the establishment of Nazareth's Peace Mosque (Jamat A-Salam). Inaugurated in 1965 , the mosque's establishment was intended to "counterbalance" the Basilica of the Annunciation and represent the Muslim residents of Nazareth, which has been the largest Arab city in Israel since 1948 (Rabinowitz, 2001, pp. 100-101). ${ }^{22}$ The mosque was funded by the Israeli government along with donations raised by the local community. ${ }^{23}$

Beyond tolerant state policy, one can see hints of interreligious dialogue in the design of Nazareth Illit's synagogue itself. In 1960, architect Nahum Zolotov's proposal was selected from among 58 entries in an architecture competition organized by the construction department of the Ministry of Social Affairs and Social Services (Amir, 2011, p. 30). ${ }^{24}$ Compared to Ben Uri's early proposal, the competition guidelines reflected a moderation of the desired prominence of the synagogue in the Nazareth region:
“The synagogue should not compete with Nazareth's churches in its height or size, but establish a structure on a human scale, suitable for the nation, the people and the environment. The structure itself should stand out precisely because of its simplicity." 25 However, despite its different sizes, functions, and meanings, the synagogue design articulates an implicit, yet consistent, architectural and artistic dialogue with the basilica.

In his research, Reuven Gafni addresses the contribution of synagogues established in Mandate Palestine to the consolidation of national identity. His work highlights the synagogues' national dimension as demonstrated, for example, by reference to historical incidents of the Yishuv (early Jewish settlement in Palestine) within the synagogue liturgy, the renewal of religious traditions, and the renaming of synagogues (Gafni, 2017). In contrast, Nazareth Illit's synagogue design reflects an attempt to construct a national landmark through its architectural features. The synagogue complex includes two prayer halls, reflecting both its local and national functions: A modest hall was intended for the daily use of the local community members. The main sanctuary and two court yards were designed to hold a large number of worshipers who gather for prayer during the Days of Awe (Rosh Hashana and Yom Kippur), as well as tourists (Fig. 4) (Amir, 2011, p. 30; Tvai, 1970).

The religiously diverse environment of the Nazareth region was always a dominant factor in the atmosphere surrounding the construction of the synagogue, as is evidenced by the metamorphosis of the town's name. Originally the town was named Kiryat Nazareth, but two years after its establishment Prime Minister David Ben Gurion declared that the name's etymology had Christian connotations. He proposed that the town be renamed Karet after an adjacent town mentioned in the Bible. ${ }^{26}$ This proposal was ignored. Instead, in 1961 the town was renamed Nazareth Illit (Upper Nazareth), evoking its geographical location on the top of a ridge of hills, above the city of Nazareth (Rabinowitz, 1997, pp. 4-6). On reflection, this name did not fulfill the intentions of the city leaders and residents. In 2019, the city was renamed Nof HaGalil (View of the Galilee) in order to demonstrate its physical and religious separation from Nazareth (Moskowitz, 2019). The ever-evolving name of Nazareth Illit demonstrates its increasing remoteness from the adjacent historical city of Nazareth. ${ }^{27}$

In the synagogue design, the drive to differentiate the building from other religious sites in the region is evident from the inverted concrete dome that covers the building. While the use of exposed concrete reflects a similarity with the Brutalist style that dominates the interior of the Basilica of the Annunciation, the inversion of the dome draws attention to the stark contrast between the synagogue and the church as parallel and yet diametrically opposed monuments. Indeed, architect Nahum Zolotov stated that the inverted dome was intended to distinguish the synagogue from Nazareth's churches and mosques. ${ }^{28}$

The architectural composition is comprised of a cube, on which sits the inverted dome. From an aerial view, the building seems to have been sunk into the hill on which it was constructed. The concrete dome is the only element exposed above the ground. Its design echoes the contour of the hill and fulfills the acoustic requirements of a prayer hall. An 'extraordinary' piece of architecture appears in the main prayer hall (Fig. 5): the dome seems to be hovering above the main hall, an illusion created by means of a long ribbon window that visually separates the dome from the walls (Harlap, 1985, pp. 128-129; Amir, 2011, p. 30).

Despite the opposition to local churches, the inverted dome reveals the inspiration Zolotov drew from a Christian landmark from further afield, namely Notre Dame du Haut Chapel (1955) in Ronchamp, France by the notable Swiss-French architect CharlesÉdouard Jeanneret (1887-1965), known as Le Corbusier. ${ }^{29}$ Both 


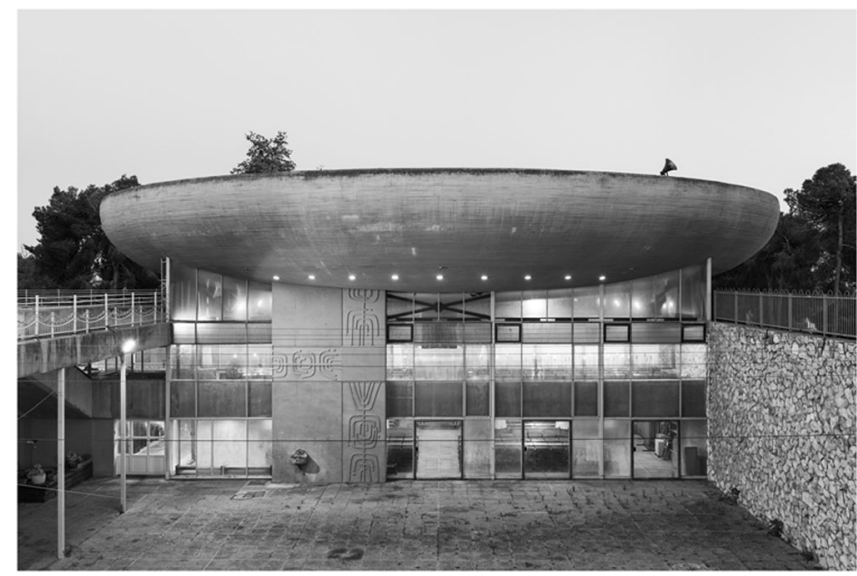

Fig. 4 The Central Synagogue of Nazareth Illit. Architect Nahum Zolotov, 1968 (Photo: Eli Singalovski, 2018).

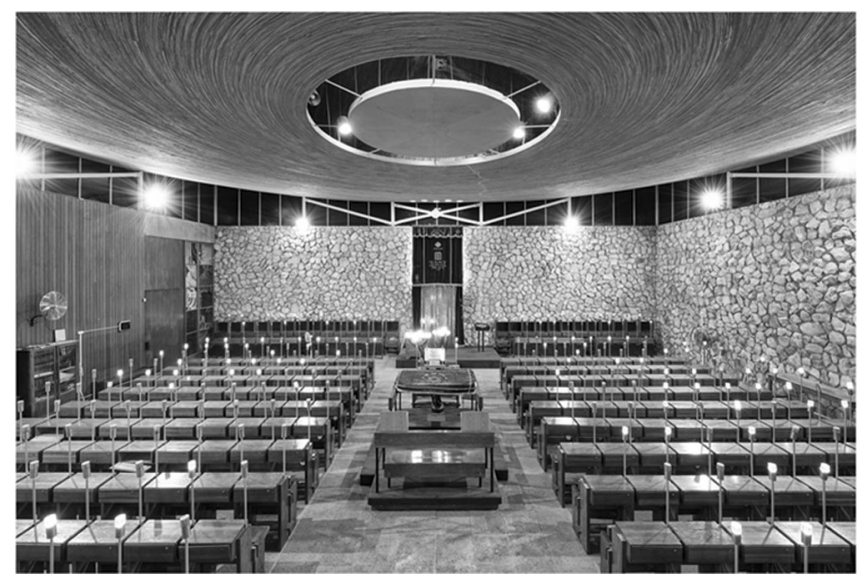

Fig. 5 The Central Synagogue of Nazareth Illit. Architect Nahum Zolotov 1968, Interior view facing the bimah and the Torah Ark. (Eli Singalovski, Nazareth Illit \#1, 2018. Archival pigment print, $100 \times 67 \mathrm{~cm}$ ).

buildings are situated on hilltops and are characterized by an expressive upturned roof and by the separation between the roof's shell and the building's envelope (Curtis, 1982, pp. 271-281). The synagogue's design appears conservative compared to the expressive design of the chapel. However, the resemblance between the projects demonstrates that projecting the distinctive character of Jewish prayer-communal participation, the two focal points of the prayer hall, and its ceremonial objects-were not the principal concerns in the architect's design.

The oeuvre of architect Nahum Zolotov's (1926-2014) is identified with a functionalist approach. His body of work includes mainly public and residential buildings, in addition to three unique synagogues through which he intended to evoke an atmosphere of holiness. ${ }^{30}$ Zolotov's style is identified with the adoption of European Brutalism, which was popular among mid20th century Israeli architects (Efrat, 2004, pp. 189-195). New Brutalism is an architectural ethic that emerged in Britain in the 1950s. The trend appeared after the second world war as a reaction to high modernism. In Israeli architecture, Brutalism was associated with an attempted to articulate a sense place through architecture, and to expose the materiality of buildings. Esthetically, the trend is identified with its raw materials, especially its characteristic exposed concrete (Nitzan-Shiftan, 2003, p. 253). ${ }^{31}$
The adoption of Brutalism in the synagogue is evident in the use of simple materials, which realized the competition guidelines: ${ }^{32}$ the walls are made of a reddish earth-colored local stone; the inverted dome and the bearing walls are made of exposed concrete and the courtyard floors are made of concrete bonded gravel (Amir, 2011, p. 31). These materials were imbued with a contemporary Israeli nation-building spirit-they were said to represent native existence, rootedness, and strength (Karmi, 2001, pp. 59-74). The adoption of Brutalism was the focus of architectural dialogue between the synagogue and the modern Basilica of the Annunciation. However, while in the basilica the exposed concrete is only visible in the interior spaces, the synagogue's concrete dome is the dominant feature of the building from both the exterior and interior viewpoints.

This comparative analysis of the synagogue and the basilica indicates that both structures adopted Brutalism. However, the inversion of the synagogue's dome articulated its distinctiveness from the houses of worship of rival religions, while at the same time reflecting the secular spirit that dominated Israeli culture at that time (Breitberg-Semel, 1986). Retrospectively, the iconic external appearance of both structures received parallel sarcastic criticism: while the dome of Basilica of the Annunciation was described as a bottle's cork (Halevi, 2010, p. 96), the inverted dome of Nazareth Illit's synagogue was compared to a dish (Ben Uri, 1961, p. 314). These reactions reflect a typical contemporary difficulty in identifying religious meaning hidden within secular form (Simhony, 2019, pp. 177-180).

The use of concrete imbued both religious buildings with connotations of power. Amiram Harlap has maintained that Israeli synagogue designs whose external appearance recalled bomb shelters represent the young state's need for a sense of security (Harlap, 1985, p. 46). However, Meir Ben Uri criticized the design of Nazareth Illit synagogue's entrance, primarily the descending concrete staircase leading worshipers from the entrance plaza to the prayer hall, for resembling the shaft of a bomb shelter. Ben Uri questioned the suitability of this architectural image for the national institution that aimed to symbolize the modern Jewish settlement in the Nazareth region (Ben Uri, 1961, p. 282). From a different point of view, the two leveled structure, and in particular the prayer halls that were sunken into the ground, may be seen as an architectural parallel of the Basilica's superimposed churches, especially the prominence of the Byzantine Grotto on the lower floor.

The adoption of Brutalism demonstrates the modernization of both institutions. However, while the basilica gained the status of an international pilgrimage site and an architectural monument that represents the universalism of the church, the synagogue functions mainly as a local icon, demonstrating the quest for the construction of a local architectural identity.

Religious art as an agent in an interreligious dialogue. The interreligious dialogue expressed through the two monuments is also revealed by a comparative examination of the artworks integrated into the synagogue and the basilica. Sacred art aims to reflect the glory of God and his creation, and to direct the worshiper's mind to spiritual concerns. Simultaneously, artworks integrated in a house of worship reflect the founder's values and ideas (Kampf, 1966, p. 26; Morgan, 2005, p. 54). ${ }^{33}$

The abundance of artworks integrated into the Basilica of the Annunciation have contributed to its status as an international tourist destination. Nurit Kenaan-Kedar indicated that the Basilica showcases both high, academic art as well as popular, folk art. High art in the basilica is exemplified by Salvatore Fiume's mosaic, situated behind the main altar in the upper Church (Fig. 6). The 


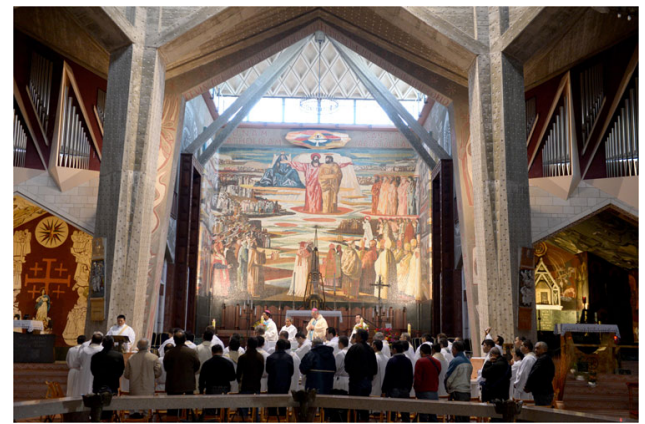

Fig. 6 Salvatore Fiume's mosaic in the Basilica of the Annunciation's upper church (Photographer unknown, 2013, National Photo Collection, Photography Department, Government Press Office, State of Israel).

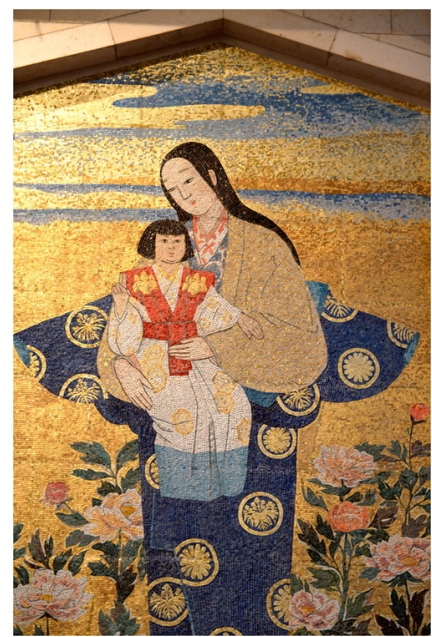

Fig. 7 Japanese Madonna and Child mosaic in the Basilica of the Annunciation's upper church (Photographer unknown, 2013, National Photo Collection, Photography Department, Government Press Office, State of Israel).

dramatic composition represents the universal church, and includes numerous figures ranging from Jesus, Mary and Saint Peter, to the church fathers and saints, and even to believers. This piece reflects a rejection of the medieval mosaic tradition and the adoption of a modern art approach (Kenaan-Kedar, 2009, pp. 82-83). In contrast, folk art expressions are demonstrated in two series of Madonna and Child panels that decorate the walls of the upper Church and hang around the walls of the open courtyard (Fig. 7) (Tessler, 2020, pp. 213-214). The panels, donated to the church by communities around the world, fuse the roles and attributes of the Virgin Mary with local characteristics of the contributing nations, and the figures therein are portrayed in traditional and folk dress. The panels are characterized by frontal flattened compositions and decorated by tapestry and prints borrowed from a range of local material cultures. For example, the panel Our Lady of the Flowers from Japan depicts the Madonna and Child as Japanese, wearing traditional Kimonos. The panel is rooted in the Japanese tradition of ink flower paintings, the flowers that surround the figure of Virgin Mary symbolize an enclosed garden (Tessler, 2020, p. 221). The Madonna panels reflect modernist adaptations of traditional Christian icons, while the multicultural and ethnically diverse images allow the Church of the Annunciation to claim to be universalist (Kenaan-Kedar, 2009, pp. 84-86; Tessler, 2020, pp. 225, 228).

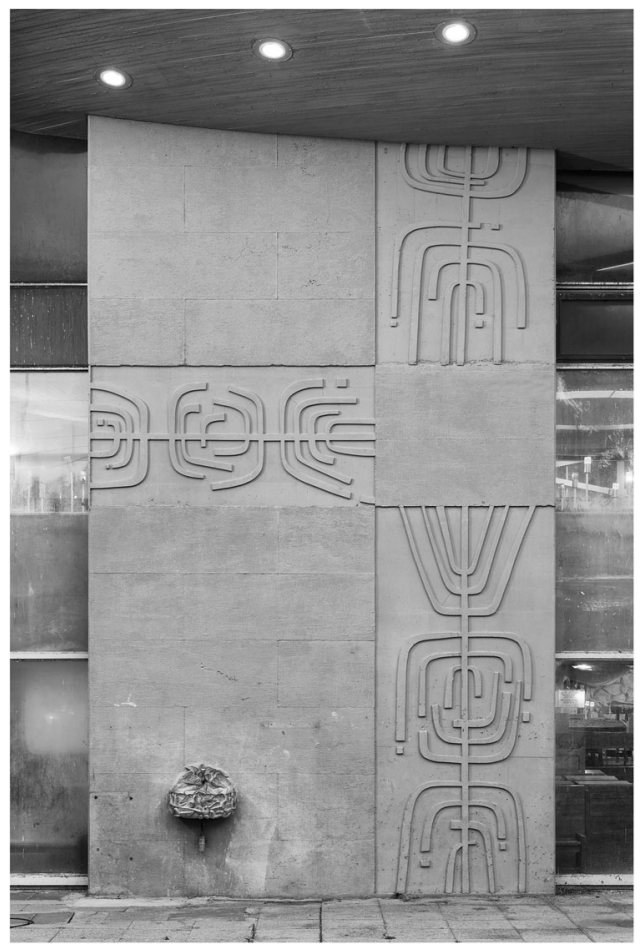

Fig. 8 Artworks at the Central Synagogue in Nazareth Illit: Ruth Zarfati and Moshe Sternschuss, a bronze basin, ca. 1968, and Ruth Zarfati, relief, ca. 1968 (Photo: Eli Singalovski, 2018).

A markedly different artistic approach characterizes the synagogue art. From the outset, the synagogue was meant to promote the town's tourism. The synagogue founders identified potential in the town's proximity to Nazareth, which was already popular thanks to its numerous religious sites and tourist attractions. The founders attempted to establish tourism in Nazareth Illit by drawing attention to the exceptional design of the synagogue and the integration of contemporary art (Carmel, 1966b). The architecture competition guidelines proposed "a Jewish spiritual center that finds expression in a Central Synagogue, which will be used not only by the local community but also by pilgrims from the diaspora." 34

This vision was realized by the integration of a range of artworks. One example is a bronze basin by Ruth Tzarfati (1928-2010) and Moshe Sternschuss (1903-1992), installed in the synagogue's lower courtyard. ${ }^{35}$ The piece features a continuous pattern of recurring doves. Another is an abstract relief also by Ruth Tzarfati installed on the same wall (Tvai, 1970). The relief is composed of a semi-abstract linear pattern that alludes to the menorah symbol (Ronen and Sternshuss (2013)). The piece is characterized by a delicate use of concrete as an art material, in contrast with the use of exposed concrete in the synagogue's architecture (Fig. 8). It is reasonable to assume that the abstracted stylistic language reveals the influence on Tzarfati of the works of landscape architect Roberto Burla Marx, such as the MES Gardens in Rio de Janeiro (1936-1943), ${ }^{36}$ as well as the influence of Le Corbusier's reliefs. ${ }^{37}$ While the menorah has been identified as a Jewish symbol since the ancient period, in modern Israel it was transformed into a national symbol of victory, evoking Jewish revival in the young state (Fine, 2016, p. 23, pp. 29-30).

In a much more traditional vein, Ruth Zarfati's stained-glass window, adjacent to the main sanctuary (Figs. 9 and 10), tells a particularly interesting story about the relationship between art and architecture in the synagogue. ${ }^{38}$ Inspired by the Jewish architectural heritage, Zolotov included the integration of 


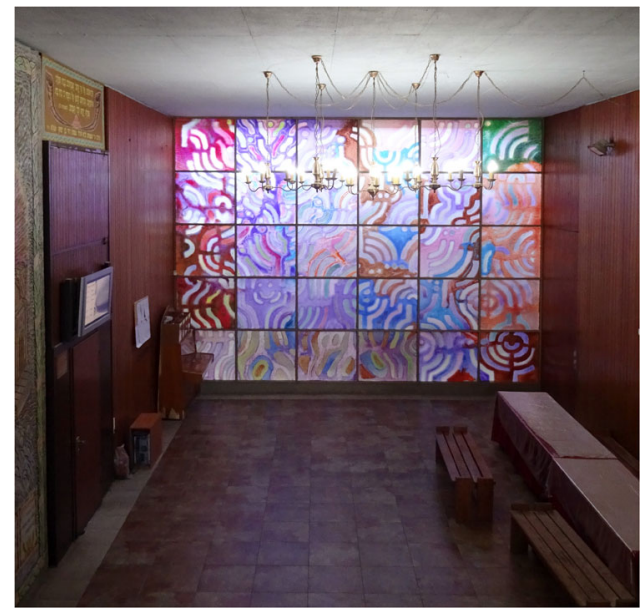

Fig. 9 Ruth Zarfati, Stained glass window at the synagogue's lower vestibule (Photo by the author, 2017).

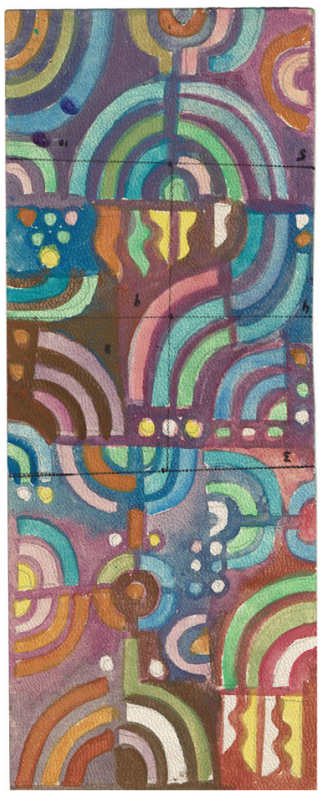

Fig. 10 Ruth Zarfati, preliminary sketch of the synagogue's stained glass window, undated, $11 \times 28 \mathrm{~cm}$ (courtesy of Zarfati collection).

artworks into the building among his design principles. However, he did not dictate the technique to be used. ${ }^{39}$ In a letter to the Nazareth Illit authorities during the construction, the designers maintained that the stained glass window would attract tourists to the synagogue. ${ }^{40}$ One can assume that the inclusion of a stained glass window among the synagogue's artworks was motivated by the fact that Basilica of the Annunciation was popularized, in part, thanks to its numerous artworks.

The Basilica of the Annunciation showcases dozens of stainedglass windows. Like the church architecture, the windows exhibit a stylistic duality: they conduct a multilayered dialogue with the Gothic European stained-glass art of the 12th century, while at the same time reflecting the influence major trends in modern art, mainly cubism and abstraction. Though stained-glass windows are considered to be Christian works of art, there is extensive precedent for their use in modern synagogues in Europe, the United States, Mandate Palestine and the State of Israel. One such example is Marc Chagall's windows in the synagogue of Hadassah Medical Center in Jerusalem, representing the twelve tribes of Israel (1962).
At first glance, the synagogue art shares its stylistic expression with the basilica. However, while the basilica's windows were imbued with symbolic religious meanings, such as the interpretation of its colors as attributes of Christ and the Virgin Mary (Segal, 2020, p. 198), the synagogue's stained glass windows recall the symbolic depictions of menorahs reminiscent of ancient mosaic floors. In doing so, the windows merge the Jewish past and present in the Galilee.

The artworks integrated into the religious buildings under examination reflect the influence of both architectural designs: as I indicated earlier, the monumental architecture of the church exhibits a stylistic duality. While the exterior appearance reflects the adoption of traditional Italian medieval models, the interior draws on twentieth-century Brutalist architecture. The influence of both architectural styles is evident in the basilica's artworks. Thus, the stained-glass windows enter into dialogue with both Gothic and modern art simultaneously (Segal, 2020, p. 193). Similarly, the synagogue's art responds to the Brutalist style of its architecture by using concrete as an art material and by adopting modern art trends, such as Cubism and abstract art.

One may question, therefore, the uniqueness of the synagogue's art, and even what makes it "Jewish" art. Skepticism of this sort echoes a widespread notion in art-historical literature that there has never been an original, Jewish artistic language, but rather that Jewish art has always imitated Christian art. Conversely, Margaret Olin maintains that Jewish art articulates specifically Jewish themes in a common language, shared by Jews and their neighbors, otherwise it would never be understood (Olin, 2009, pp. 84, 86-88).

Ultimately, the religious artworks under examination represent a blend of traditional meanings and modern forms. Art historian Alan Powers maintains that religious art, such as both case studies under examination here, show how modernity removed the need for any explicit adherence to a faith tradition. Instead, this combination of style and motif can be explained as an expression of modern culture's dialectic relationship with religion, which was articulated in the arts by means of abstraction (Powers, 2019, p. 14).

\section{Conclusions: constructing Jewish-national identity in an interreligious environment}

Historian of religion Catherine L. Albanese defines a religion as a system of symbols through which people orient themselves in the world. These symbols reference ordinary and extraordinary meanings, values and powers, which surpass the domain of everyday experience (Albanese, 1992, p. 11). By the term Extraordinary Religion, Albanese refers to the boundary between mundane encounters and some form of otherness, natural or supernatural (Albanese, 1992, p. 11; Morgan, 2005, p. 53). Morgan maintains that the distinction between ordinary and extraordinary bears special relevance for the study of religious visual culture, since images mark boundaries in the formal and informal aspects of lived religion (Morgan, 2005, pp. 53-54). In this article, I explored the boundary between the formal and informal functions of Nazareth Illit's Central Synagogue; between its formal religious function as a house of worship and the informal ways in which its modern religious architecture serves as an agent in a struggle for local religious prominence.

Analyzing the architectural dialogue between Jewish and Christian religious structures reflects a complex story, albeit one that involves coexistence and cooperation. This dialogue was desired and motivated by the Israeli authorities in an attempt to both mobilize and exploit Nazareth's status as a worldwide pilgrimage site in order to attract tourism to Nazareth Illit and strengthen the Jewish presence in the Galilee. 
Ultimately, the idea of formulating interreligious dialogue through architecture in Nazareth's multi-religious environment remained unrealized. This was a result of the ethno-political, cultural and environmental differences between Nazareth and Nazareth Illit, along with the differences in the projects' scales and budgets. These conditions enhanced the separation between the religious sites in the adjacent towns. This complex story illustrates the role of western identity and architectural motifs as a tool for the consolidation of a self-conscious Israeli national entity (Chinski, 2015, pp. 155-160). While contemporary Israeli architectural discourse was dealing with the search for a sense of locality, the Central Synagogue of Nazareth Illit, the Jewish national icon of the Galilee, remained rooted in western European culture.

\section{Data availability}

All data generated or analyzed during this study are included in this published article.

Received: 11 May 2020; Accepted: 4 November 2020;

Published online: 09 December 2020

\section{Notes}

1 Throughout this article I will refer to the town as Nazareth Illit, as this was the town's name during the period under investigation.

2 The development town was originally named Kiryat Nazaret (lit. Nazareth town). In 1958 the name Nazareth Illit (lit. upper Nazareth) was adopted, and in 1961 Nazareth Illit was recognized a city. In 2019, the city was renamed Nof HaGalil (lit. Galilee Landscape). Hereafter: "Nazareth Illit" (see Moskowitz, 2019).

3 David Ben Gurion's statement was reproduced in 1987 in an official publication issued for Nazareth Illit's 13th anniversary (quoted in Rabinowitz, 1997, p. 6). 4 Mordechai Alon in an interview with Tuvia Carmel (see Carmel, 1966a).

5 "A survey of religious institutions in Nazareth-Illit."Nazareth Illit: A Monthly Newsletter for the Resident, Edited by Levi Olami (October 1, 1969): 6. Israel State Archives (ISA), GL-50917/2. [All translations from the Hebrew are my own unless otherwise indicated.]

6 This paper was first presented at Extra-Ordinary: Unique and Common Artifacts as Social Actors International workshop held at the Mandel Scholion Center at Hebrew University of Jerusalem in December 2018. In February 2020, the author attended a symposium dedicated to Nahum Zolotov's works, hosted by the Azrieli Architectural Archive at Tel Aviv Museum of Art, where Prof. Arch. Eran Neuman lectured about the same topic (Neuman, 2020). The paper is based on the author's ongoing Ph.D. research at the Hebrew University of Jerusalem, which investigates synagogue architecture in Israel's first two decades of statehood and its contribution to the consolidation of a new Jewish national identity.

7 Though it is beyond the scope of this article to fully explore local mosques in the regions religious struggles, such tendency was echoed in Nazareth's history by the crisis over Nazareth's Shihab al-Din Mosque. The struggle surrounded a proposal for the construction of a Mosque in a plot in front of the Basilica of the Annunciation. The Vatican objected to the construction due to the proposed structure's proximity to the Basilica and to its height. The planed Mosque was supposed to hide the Basilica and compete with it for dominance of the city's skyline. In 2000, the Israeli government decided to halt the Mosque's construction, though it continued illegally. In 2003, the Mosque's foundations were demolished (see Myre, 2003; Rabinowitz 2001). Dan Rabinowitz maintains that this demolition demonstrates how a consecrated place can be mobilized for marking and policing boundaries between religious groups (Rabinowitz, 2001, p. 109). It is noteworthy to make a comparison with the design history of the 2019's Camilca Mosque in Istanbul, Turkey, which was constructed in front of Aya Triade Church (see Batuman, 2018, pp. 31-36).

8 For recent studies presenting a comprehensive investigation of Jewish architecture in different historical and geographical contexts, see, for example, Jarrasse (2001), Kessler and Kienlin (2015), Fine (2019), and Gharipour (2017).

9 The basilica was an ancient Roman public building, where courts and other official functions were held. The basilica contained a large hall divided into a nave and side aisles by rows of columns which supported the roof, and served as a meeting place, a court of law, or a public bathhouse (see Wischintzer, 1964, pp. xxvii-xxviii; Krinsky, 1985 , p. 15). For comparisons between ancient synagogue and church architecture see Hachlili (1997) and Rosenau (1940-1941).

10 For publications dedicated to modern church architecture and art, see Segal et al. (2020), Kieckhefer (2004), Heathcote and Moffatt (2007), and Proctor (2014).
11 Israeli synagogue architecture has not yet been comprehensively examined in the field of History and Theory of Architecture. Nurit Kenaan-Kedar has described a similar lack of research literature dedicated to Christian architecture and art in the modern Land of Israel (Kenaan-Kedar, 2009). For investigation of ancient, medieval and early modern synagogue architecture. For example, see Levine (2000a), Pinkerfield (1945), Krautheimer (1994), Fine (1996), Jarrasse (2001), Kravtsov and Levin (2017), and Fine (2019). For investigation of modern and contemporary synagogues in Europe and the United States, see for example: Wischnitzer (1955), Krinsky (1985), Gruber (2003), Britton (2011), and Geva (2012). For studies dedicated to Jewish art, see Kampf (1966), Cecil Roth (1974), Sabar (1996), Bland (2001), and Olin (2001). Very little research has been dedicated to synagogues constructed in the State of Israel. The most comprehensive work dealing with synagogue architecture in Israel was written by architectural historian Amiram Harlap (1985). The contemporary literature mainly consists of anthologies published by government institutions to guide designers of Israeli synagogues (HaCohen, 1955).

12 For an investigation of the adoption of the Brutalism in contemporary Israeli architecture, see Nitzan-Shiftan (2003, pp. 231-255).

13 "Nazareth's Synagogue-Conditions of the Open-Limited Competition," 24.7.1959, Meir Ben Uri Archive, Haifa, "Nazareth, materials for the design competition and jury protocol. 320.10-0" [Hebrew].

14 Meir Ben Uri in a letter to the Minister of Religions Rabbi Ya'acov Moshe Toledano. June 10, 1959. Meir Ben Uri Archive, Kiryat Nazareth synagogue, 320.00-0 [Hebrew]

15 Maximilian Wasbutzky was enrolled in a bachelor's degree in architecture during the academic years 1928-1930. Claudia Schülzky, the Technical University of Berlin's archive, in an email correspondence with the author, October 15, 2019.

16 Meir Ben Uri, “Concepts for the design for Nazareth's Central Synagogue-to the Minister of Religions”, 1957. Meir Ben Uri Archive, Kiryat Nazareth synagogue, 320.00-0 [Hebrew].

17 Established in Jerusalem in 1906, the Bezalel Academy of Arts and Design was a pioneering institution for the visual arts in Israel during the 20th century. In their efforts to formulate a distinctive national style for the new country, Bezalel artists blended biblical themes, local landscapes, Jewish symbols, oriental art and European traditions (Zalmona, 1998, pp. 48-49; Olin, 2001, pp. 5-31).

18 Meir Ben Uri in a letter to Mr. A. I. Lebanon, Director of the Ministry of Religions November 28, 1958. Meir Ben Uri Archive, Kiryat Nazareth synagogue, 320.00-0 [Hebrew].

19 For a comprehensive examination of the political controversy behind the establishment of the Basilica of the Annunciation (see Halevi, 2008).

20 Gambirasio G, Minardi B (eds) (1982) Giovanni Muzio. Opere e scritti. Franco Angeli, Milan (cited in Irace, 2020, p. 103).

21 "The Establishment of the Basilica of the Annunciation Begins" HaBoker (July 1960): 6 [Hebrew].

22 Today Nazareth is the largest Palestinian urban center inside Israel. Its population of $\sim 65,000$ inhabitants, includes about 20,000 Christians. The war of 1948 brought considerable demographic change to Nazareth, as only a relatively small proportion of Nazarenes were forced to leave, while as many as 20,000 Muslim Palestinian internal refugees fled into Nazareth and grew the population to 35,000 (Rabinowitz, 2001, p. 101).

23 "A Mixture of Holiness and Profane", HaBoker (January 7, 1965): 5 [Hebrew].

24 "Nazareth's Synagogue: Conditions of the Open-Limited Competition," ca. 1959, Meir Ben Uri Archive, Haifa. Nazareth Synagogue Competition. 320.10-0" [Hebrew]

25 Jury meeting protocol, May 19, 1959. Participants: Y. Dekel, A. Hashin, H. Martans, A. Neumann, H. Pavel. Meir Ben Uri Archive, Haifa. Nazareth Synagogue Competition. 320.10-0" [Hebrew]

26 Israel Government meeting protocol, March 29, 1959. "Minutes of government meetings in 1959" Israel State Archives [Hebrew] (see also Moskowitz, 2019; Shapira, 1997)

27 The shifts in Nazareth Illit's names are associated with a trend of attaching biblical-historical names to sites and settlements, with the aim of projecting the Jewish identity of space (see Shachar and Nitzan-Shiftan, 2014, pp. 104-105).

28 Nahum Zolotov, interviewed by the author, Hod HaSharon, November 9, 2009.

29 Architect Meir Ben Uri was the first to point at the resemble between the projects (see Ben-Uri, 1961).

30 Zolotov synagogue designs include the inter-communal synagogue in Be'er-Sheva (1958) and the Babylonian community synagogue in Be'er-Sheva (1980). Amir, Nahum Zolotov, 5; Nahum Zolotov, interviewed by the author, November 9, 2009.

31 For an account of Brutalism in contemporary architectural criticism literature, see Benham (1966). For an account on the adoption of the trend in Israeli architecture, see Nitzan-Shiftan (2003).

32 "Nazareth's Synagogue: Conditions of the Open-Limited Competition".

33 For further investigation of religious art, see Lanwerd (2006), Begbie (1997), Cecil Roth (1974), Kenaan-Kedar (2014) and Keshman (2005, 2013).

34 "Nazareth's Synagogue: Conditions of the Open-Limited Competition," ca. 1959, Meir Ben Uri Archive, Haifa. Nazareth Synagogue Competition. 320.10-0" [Hebrew].

35 Hagit Sternschuss Amram, daughter of Sternschuss and Zarfati, telephone interview by the author, 21 August 2019.

36 For an investigation of the MES gardens, see Fraser (2000). 
37 For an investigation of Le Corbusier relief Unite' d'habitation, Marseille (1947-1953) (see Curtis, 1982, pp. 284-294).

38 For an account of Ruth Zarfati and Moshe Moshe Sternschuss' synagogue artworks (see Naomi Simhony), "Exceptionally Jewish: Israeli Synagogue Architecture in the 1960s and 1970s." Arts, 9, 21 (2020): 7-9.

39 Nahum Zolotov, Architect's statement for a local newspaper, Nazareth Illit, undated. Architect's collection.

40 A meeting protocol, December 29, 1968. Nazareth Illit. Nazareth Illit Archive, 98: 1-8 [Hebrew]

\section{References}

Albanese C (1992) America, religions and religion. Wadsworth, Belmont

Amir T (2011) Nahum Zolotov: architect and city planner. Ama, Tel Aviv [Hebrew]

Bar D (2015) Fifty years since the visit of Pope Paul VI in Nazareth (January 1964): the Israeli context. Cathedra 160:123-152. [Hebrew]

Batuman B (2018) New Islamist architecture and urbanism: negotiating nation and Islam through built environment in Turkey. Routledge, London and New York

Begbie J (1997) Christ and the cultures: Christianity and the arts. In: Gunton CE (ed.) The Cambridge companion to Christian doctrine. Cambridge University Press, Cambridge, pp. 101-120

Benham R (1966) The new Brutalism: ethic or esthetic? Reinhold, New York

Ben-Uri M (1961) A lesson from the competition for the design of the synagogue in Nazareth-Illit. Eng Archit 11:280-282. 314 [Hebrew]

Bland KP (2001) The artless Jew: medieval and modern affirmations and denials of the visual. Princeton University Press, Princeton

Breitberg-Semel S (1986) The want of matter: a quality in Israeli art. In: BreitbergSemel S (curator) The want of matter: a quality in Israeli art, Exhibition Catalogue. Tel Aviv Museum of Art, Tel Aviv.

Britton K (2001) Auguste Perret. Phaidon, London

Britton K (2011) Constructing the ineffable: contemporary sacred architecture. Yale University Press, New Haven

Britton K (2012) Concern for the spirit: a history of modern church architecture. Sacred architecture 22:27-33

Carmel T (1966a) And this is the history of Nazareth Illit. Ma'ariv [Hebrew].

Carmel T (1966b) An inverted dome at the Center of a Synagogue. Ma'ariv [Hebrew]

Cecil Roth B, Narkiss B (eds) Jewish art: an illustrated history. pp 97-106. [Hebrew] English edition: Cecil Roth B, Narkiss B (1971) Jewish art: an illustrated history. Massada, Jerusalem

Chinski S (2015) Kingdom of the meek: the social grammar of the Israeli art field. Hakibbutz Hameuchad, Tel Aviv [Hebrew]

Christ-Janer A, Mix M (1962) Modern church architecture: a guide to the form and spirit of twentieth century religious buildings. MacGraw-Hill, New York

Curtis WJR (1982) Modern architecture since 1900. Phaidon, Oxford

Efrat Z (2004) The Israeli project, building and architecture, 1948-1973. Tel Aviv Museum of Art, Tel Aviv

Fine S (ed.) (1996) Sacred realm: the emergence of the synagogue in the ancient world. Oxford University Press, Yeshiva University Museum, New York, Oxford

Fine S (ed.) (2016) Who is carrying the Temple menorah? A Jewish counternarrative of the Arch of Titus Spolia Panel. Images 9: 1-30.

Fine S (ed.) (2019) Jewish religious architecture: from biblical Israel to modern Judaism. Brill, Leiden, Boston

Fischer Y, Manor-Friedman T (2008) Conversations. In: Fischer Y, ManorFriedman T (eds) The Second Decade: The Birth of Now-Art in 1958-1968. Ashdod: Ashdod Museum, pp. 9-10

Forty A (2012) Concrete and culture: a material history. Reaktion, London

Fraser V (2000) Cannibalizing Le Corbusier: the MES gardens of Roberto Burle Marx. J Soc Archit Hist 59(2):180-193

Gafni R (2012) Shaping Jewish nationalism in synagogues in Eretz Israel during the British Mandate Period. The Hebrew University of Jerusalem [Hebrew].

Gafni R (2017) Under the dome of the nation: synagogues and Jewish nationalism in the Yishuv during the British Mandate. The Ben-Gurion Research Institute for the study of Israel and Zionism, Ben Gurion University of the Negev [Hebrew].

Gafni R (2014) The attempt to establish a synagogue in memory of the Saints of Krakow and the Rama in Kfar Etzion, 1947. Al A'tar, pp. 59-76 [Hebrew]

Geva A (2012) Frank Lloyd Wright's sacred architecture: faith, form and building technology. Routledge, New York

Gharipour M (2017) Synagogues in the Islamic world: architecture, design, and identity. Edinburgh University Press, Edinburgh

Gruber SD (2003) American synagogues: a century of architecture and Jewish community. Rizzoli, New York

Hachlili R (1997) Aspects of similarity and diversity in the architecture and art of ancient synagogues and churches in the Land of Israel. Zeitschrift des Deutschen Palastina-Vereins 113:92-122
HaCohen M (ed.) (1955) The synagogue: articles and essays. Ministry of Religious Affairs, Government Publishing House, Jerusalem [Hebrew].

Halevi M (2004) Religion, symbolism and politics: symbolic and political perspectives on the establishment of the modern Basilica of the Annunciation in Nazareth. MA Thesis, The Hebrew University of Jerusalem [Hebrew].

Halevi M (2008) The intra-church debate regarding the establishment of Nazareth's Church of the Annunciation. Cathedra 126:85-86. [Hebrew]

Halevi M (2010) The politics behind the construction of the modern Church of the Annunciation in Nazareth. Cathol Hist Rev 96.1:27-55

Harlap A (1985) Synagogues in Israel from the ancient to the modern. Ministry of Defense and Dvir, Tel Aviv

Heathcote E, Moffatt L (2007) Contemporary church architecture. Willey Academy, Grat Britain

Irace F (2020) From Milan to the Holy Land: Giovanni Muzio in Nazareth. In: Segal E, Pinkus A, Fishhof G (eds) The Basilica of the annunciation in Nazareth: where the word became flesh. De Gruyter, Berlin/Boston, pp. 95-104

Jarrasse D (2001) Synagogues: architecture and Jewish identity. Abrams, New York

Kampf A (1966) Contemporary synagogue art: developments in the United States, 1945-1965. Union of American Hebrew Congregations, New York

Karmi R (2001) Brutalism. In: Karmi R ed Lyric architecture. Ministry of Defense, Israel, pp. 59-74. [Hebrew]

Kenaan-Kedar N (2009) The Madonna of the prickly pear cactus: tradition and innovation in 19th and 20th century Christian art in the Holy Land. Yad BenZvi, Jerusalem [Hebrew]

Kenaan-Kedar N (2014) Introduction: the church, its patrons and the artists. In Kenaan Kedar N (Ed.) Hidden oeuvre: Christian art in the Holy Land 1741-1969. Resling, Tel Aviv, [Hebrew] 9-16

Keshman A (2005) The origins of anthropomorphic reliquaries. Dissertation, The Hebrew University of Jerusalem.

Keshman A (2013) Crusader wall mosaics in the Holy Land. Gustav Kühnel's work in the Church of the Nativity in Bethlehem. Arte Medievale, S.IV, III, pp. 249-262.

Kessler K, Kienlin A (eds) (2015) Jewish architecture in Europe: new sources and approaches. Michael Imhof Verlag, Petersberg

Kieckhefer R (2004) Theology in stone: church architecture from Byzantium to Berkeley. Oxford University Press, New York

Krautheimer R (1994) Synagogues in the Middle Ages (Hebrew trans Goren A) Bialik Institute, Jerusalem

Krautheimer R (1927) Mittelalterliche Synagogen. Frankfurter Verlags-Anstalt, Berlin

Kravtsov SR, Levin V (2017) Synagogues in Ukraine: Volhynia. The Zalman Shazar Center for Jewish History, Jerusalem

Kravtsov SR (2010) Gothic survival in synagogues of eastern Europe. In: Mushlin AC, Theies HH (eds) Jewish architecture in Europe. Michael Imhof Verlag, Petesberg, pp. 101-107

Kravtsov SR (2016) Architecture of 'New Synagogues' in central-eastern Europe. In: Brämer A, Przystawik M, Thies HH (eds) Reform Judaism and architecture. Michael Imhof Verlag, Petesberg, pp. 47-78

Krinsky CH (1985) Synagogues of Europe: architecture, history, meaning. Architectural History Foundation, New York

Lanwerd S (2006) Art religion. In: von Stuckrad K (ed) The Brill dictionary of religion. Brill, Leiden, Boston, pp. 135-137

Levine IL (2000a) The ancient synagogue: the first thousand years. Yale University Press, New Haven

Levin IL (2000b) Judaism and Hellenism in antiquity: conflict or confluence? The Zalman Shazar Center, Jerusalem [Hebrew]

Longhi A (2020) The Second Vatican Council and ecclesiastical architecture: liturgy, modernity, memory. In: Segal E, Pinkus A, Fishhof G (eds) The Basilica of the Annunciation in Nazareth: where the word became flesh. De Gruyter, Berlin/Boston, pp. 69-94

Marshall BD (1997) Christ and the cultures: the Jewish people and Christian theology. In: Gunton CE (ed) The Cambridge companion to Christian doctrine. Cambridge University Press, Cambridge, pp. 81-100

Morgan D (2005) The sacred gaze: religious visual culture in theory and practice. University of California Press, Berkeley

Moskowitz I (2019) Nazareth Illit changes name to differentiate from biblical Nazareth Ynetnews. https://www.ynetnews.com/articles/0,7340,L-5477002,00.html

Mumford L (1925) Towards a modern synagogue architecture. Menorah J XI:225-36

Myre G (2003) In a Christian-Muslim dispute, Israel blocks a new mosque. The New York Times.

Neuman E (2020) The Annunciation according to Zolotov. Nazareth-Nazareth Illit: The Basilica of the Annunciation and the Central Synagogue in Nazareth Illit. Paper presented at a conference on occasion of the exhibition Human, Pattern: Works from the Nahum Zolotov Collection, Azrieli Architectural Archive, Tel Aviv Museum of Art, 13 February 2020.

Nitzan-Shiftan A (2003) Seizing locality in Jerusalem. In: AlSayyad N (ed) The end of tradition? Routledge, London, New York, pp. 231-255 
Olin M (2001) The nation without art: examining modern discourses on Jewish art. University of Nebraska Press, Lincoln

Olin M (2009) Jewish art and our national past time. Images 3:83-101

Pinkerfield J (1945) The synagogues of Eretz Israel from the end of the Geonim era to the rise of Hasidism. Central Press, Jerusalem [Hebrew]

Pincus-Witten (1976) Jewish art: six hypotheses. Mussag 10: 55-57 [Hebrew].

Powers A (2019) Art, faith and modernity. In: Llewellyn S, Liss P (eds) Art, faith and modernity. Liss Llewellyn, pp. 11-28.

Proctor R (2014) Building the modern church: Roman Catholic church architecture in Britain, 1955 to 1975. Ashgate, England, Vermont

Rabinowitz D (1997) Overlooking Nazareth: the ethnography of exclusion in Galilee. Cambridge University Press, Cambridge

Rabinowitz D (2001) Strife in Nazareth: struggles over the religious meaning of place. Ethnography 2(1):93-113

Ronen A, Sterenshuss H (2013) Ruth Zarfati: the joy of creation, sculptures and paintings. Cat. Ramat Gan Museum of Art, Ramat Gan [Hebrew]

Rosenau H (1940-1941) The synagogue and protestant church a rchitecture. J Warbg Court Inst 4(1-2):80-84.

Sabar S (ed.) (1996) And I crowned you with wreaths: the international Judaica design competition. Kal Graf Studio, Jerusalem

Sabar S (ed) (2000) Synagogue interior decoration and the Halakhah. In: Dorfman R, Dorfman, BZ (eds) Synagogues without Jews and the communities that built them. Jewish Publication Society, Philadelphia, pp. 308-317.

Segal E, Pinkus A, Fishhof G (2020) Introduction. In: Segal E, Pinkus A, Fishhof G (eds) The Basilica of the Annunciation in Nazareth: where the word became flesh. De Gruyter, Berlin/Boston, pp. 7-16

Segal E (2020) The creation of light: tradition and innovation in the stained-glass windows in the Basilica of the Annunciation. In: Segal E, Pinkus A, Fishhof G (eds) The Basilica of the Annunciation in Nazareth: where the word became flesh. De Gruyter, Berlin/Boston, pp. 193-209

Shachar O (2012) A circular world-a right angle world: modern architectures and urban communities at Hatzor Ha'Glilit 1950-1976. Dissertation, The Technion-Israel Institute of Technology [Hebrew]

Shachar O, Nitzan-Shiftan A (2014) A circular world-a right angle worldbetween Tel Hazor and the tomb of Honi HaMe'agel, Zehuyot (Identities) J Jew Cult identity 5:99-130 [Hebrew]

Shalev-Eyni S (2014) Reconstructing Jerusalem in the Jewish liturgical realm: The Worms synagogue and its legacy. In: Kuhnel B et al. (ed.) Visual Constructs of Jerusalem. Brepols, Turnhout, pp. 161-169

Shapira A (1997) Ben Gurion and the Bible: the forging of a historical narrative. Middle East Stud 33:645-674

Simhony N (2018) Concrete folklore. In Simhony N, Gordon D (Curators) Concrete folklore: experimental architecture in Israeli synagogues in the 1960s and 1970s. Cat. Israel Association of Architects and Urban Planners, Israel [English and Hebrew].

Simhony N (2019) The modern Israeli synagogue as an experiment in Jewish tradition. In: Gitler IBA, Geva (eds) Israel as a modern architectural experimental lab. Intellect Books, Bristol and Chicago, pp. 173-198.

Simhony N (2020) Exceptionally Jewish: Israeli synagogue architecture in the 1960s and 1970s. Arts 9 21:1-19

Snyder SC (2013) Building a public Judaism: synagogues and Jewish identity in nineteenth-century Europe. Harvard University Press, Cambridge

Talgam R (2004) Comments on the Judeo-Christian dialogue in the mosaic floor of the Sepphoris' synagogue. In: Eshel Y, Netzer E, Amit D, et al. (eds) And let them make me a sanctuary: synagogues from ancient times to the present day. Ariel Academic Center of Samaria, Ariel, pp. 77-86. [Hebrew]

Talgam R (2000) Similarities and differences between synagogue and church mosaics in Palestine during the byzantine and Umayyad periods. In: Levine
LI, Weiss Z (eds) From Dura to Sepphoris: studies in Jewish art and society in late antiquity. J Roman Archaeol Suppl 40:93-110

Tessler N (2020) Flowers of the Madonna in the Church of the Annunciation: symbolic, multicultural, and transcultural meanings. In: Segal E, Pinkus A, Fishhof G (eds) The Basilica of the Annunciation in Nazareth: where the word became fesh. De Gruyter, Berlin/Boston, pp. 211-228

Tvai (1970) The Central Synagogue Nazareth. Tvai 8: 58-61 [Hebrew].

Wischnitzer R (1955) Synagogue architecture in the United States: history and interpretation. The Jewish Publication Society of America, Philadelphia

Wischnitzer R (1964) The architecture of the European synagogue. Jewish Publication Society, Philadelphia

Zalmona Y (1998) To the East? To the East! On Orientalism in the Arts in Israel. In: Zalmona Y, Manor-Friedman T (eds) To the East: Orientalism in the Arts in Israel, Exhibition Catalogue. Jerusalem: The Israel Museum

\section{Acknowledgements}

This article is based on the author's on-going Ph.D. research project, supported by the Mandel-Scholion Interdisciplinary Research Center in the Humanities and Jewish Studies at the Hebrew University of Jerusalem; The International Leo Baeck Fellowship Program, BMBF-Studienstiftung and Leo Baeck Institute London; and the Rachel Yanait Ben-Zvi Fellowship Program, Joint Center for the Study of the Land of Israel-Yad Izhak Ben-Zvi and the Faculty of Humanities of the Hebrew University. I deeply thank Architect Nahum Zolotov, Tali Tzuker-Zolotov, Shaul Lavi, Yosef Toister, Rabbi Isaiah Herzel, and Yair Ben Uri, for their willingness to share their knowledge and thoughts, and for the invaluable archival materials they provided. Special thanks go to Shalom Sabar, Roy Kozlovsky for their valuable comments on earlier versions of this paper. Many thanks to Eli Singalovski for his permission to include his photographs in this article.

\section{Competing interests}

The author declares no competing interests.

\section{Additional information}

Correspondence and requests for materials should be addressed to N.S.

Reprints and permission information is available at http://www.nature.com/reprints

Publisher's note Springer Nature remains neutral with regard to jurisdictional claims in published maps and institutional affiliations.

\begin{abstract}
(c) (i) Open Access This article is licensed under a Creative Commons cc. Attribution 4.0 International License, which permits use, sharing, adaptation, distribution and reproduction in any medium or format, as long as you give appropriate credit to the original author(s) and the source, provide a link to the Creative Commons license, and indicate if changes were made. The images or other third party material in this article are included in the article's Creative Commons license, unless indicated otherwise in a credit line to the material. If material is not included in the article's Creative Commons license and your intended use is not permitted by statutory regulation or exceeds the permitted use, you will need to obtain permission directly from the copyright holder. To view a copy of this license, visit http://creativecommons.org/ licenses/by/4.0/.
\end{abstract}

(C) The Author(s) 2020 